\title{
Agronomic performance of Indian wheat varieties and genetic stocks known for outstanding chapati quality characteristics
}

\author{
Satish Kumar*, V. S. Sohu, and N. S. Bains \\ Department of Plant Breeding and Genetics, Punjab Agricultural University, Ludhiana -141004 (Punjab), INDIA \\ *Corresponding author. E-mail: kumarsatish227@gmail.com \\ Received: June 19, 2017; Revised received: September 4, 2017; Accepted: January 20, 2018
}

\begin{abstract}
The aim of the present study was to evaluate set of wheat genotypes in one location for their agronomic performance and chapati quality. The cultivars included the tall traditional wheat of the pre-dwarfing era, which were known to excel for chapati quality. This set also included varieties known to have good chapati quality, commercially grown wheats, advanced lines and genetic stocks excelling in one or other quality attribute. All these genotypes developed for different component traits were evaluated along with the recently released high yielding varieties to assess their quality. The mean chapati score of these genotypes revealed that the tall varieties had a distinct edge over others and are the best resource available for this trait. C306 had a high mean chapati score of 8.17 followed by C518, C591 and C273. The released varieties WG357, HD2733 and PBW343 were intermediate in chapati quality whereas the genetic stocks WH1103 and WH712 had lowest score in the group. Among other agronomic traits recorded the traditional varieties were tall and had lower yields than the recently released varieties. The tall varieties had a slightly higher test weight. The environmental conditions and the quantitative nature of the chapati quality did not auger well with the set of genotypes tested however, better and stable performance of the tall traditional varieties. C306 the wheat variety released in 1965 for cultivation has remained the best quality genotype over the years and was also established from this study.
\end{abstract}

Keywords: Chapati quality, C 306, Tall traditional wheats, Wheat

\section{INTRODUCTION}

Wheat is the leading cereal grain produced, consumed and traded in the world. During 2015-16 total wheat production of wheat in world was $736 \mathrm{MT}$ with a consumption of $720 \mathrm{MT}$ (Source: International Grains Council (IGC), 2017). In the Indian sub-continent and parts thereof, wheat is consumed as unleavened, single -layered flat bread, commonly known as chapati. During 2016-17 total wheat production of wheat in India was 97.44MT with a consumption of more than 90.0MT (Anonymous, 2017). Just as bread is a staple food item in the western world, chapati prepared from whole wheat meal (locally known as atta) is the staple diet of a sizable population of Indian sub-continent. India harbours about 1.25 billion people which amount to about 18 per cent of total world populations. Out of these more than 80 per cent consume wheat in the form of chapati. Not only in India but the adjoining countries Pakistan, Nepal, Bangladesh and Bhutan also prefer 'chapati' as their main food item. These facts emphasize the importance of this end product of wheat and also underline the need for an in-depth analysis of 'chapati' quality.

The quality of wheat, as far as chapati is concerned, is relative. The concept of good chapati varies from re- gion to region, as also on the preparation. However, a soft and pliable texture, creamish colour, pleasing flavour and sweet taste along with good puffing and long keeping quality are recognized as desirable quality attributes of good chapaties everywhere (Kumar, 2009). Studies on chapati quality have been devoted mainly to standardization of laboratory tests and comparison of available cultivars (Austin and Ram, 1971; Abrol, 1972; Finney et al., 1973; Bakshi et al., 1979; Mishra, 1998; Singh et al., 2016; Panghal et al., 2017). Though several studies have been conducted on the technological aspects of chapati processing, the underlying indices that can be used for selection and the genetic basis of chapati quality, remain incompletely understood, particularly in comparison to similar studies on bread making. As a consequence, significant progress for chapati quality has not been made in Indian wheat breeding programmes over the last four decades.

The superiority of tall wheats (C 306, C 273, C 591, etc.) grown in North India before the advent of semidwarf varieties, has been documented for various quality traits such as grain hardness (Austin and Ram, 1971), keeping quality of chapati (Abrol, 1972), color, texture and flavour of chapati (Mishra, 1998), etc. C 306 , a variety released more than four decades ago in 
1965 , originally rainfed condition but its popularity among chapati consumers has taken it to marginal irrigated areas. Out of about 180 wheat varieties released in the country till then, none was found to surpass C 306 for chapati- making quality (Mishra, 1998). It is widely acknowledged that the chapaties made from modern, improved, high yielding varieties do not have the above desirable characteristics to the same extent as those found in chapaties prepared from indigenous (desi) wheats (Austin and Hanslas, 1983). With the advent of semi-dwarf varieties in mid 1960s, the chapati making quality of traditional tall Indian wheats of the pre semi-dwarf era was eroded and no serious effort was made to recapture this trait in the new high yielding varieties.

Other than C 306, wheat varieties popular for good chapati quality evolved in different eras/periods. Lok 1 released in 1982 and Raj 1482 released in 1983 for central zone have been preferred by consumers for their superior chapati quality over the semi-dwarf wheats. 1990's saw the release of wheats such as PBW 154, PBW 175, Raj 3765 and later the varieties HD 2733, GW 322 were released in 2001 and 2002 (Das et al., 2006; Hemalatha et al., 2006). All these genotypes were known to have good chapati quality. As mentioned earlier none of the genotypes could surpass C 306 for its chapati making qualities. And also they were released in different eras and for different agro climatic zones, comparative information is either lacking or anecdotal i.e. not supported by any concrete data.

Since chapati making quality is a complex trait involving various components, development of genetic stocks for each component has been carried out in last decade. These genetic stocks are evaluated for yield and quality every year under Quality Component Screening Nursery (QCSN) (Anonymous 2017). These genetic stocks can be an important part of the breeding programme for wheat quality. Thus these stocks along with the varieties mentioned above need to be put together under one environment to evaluate for yield and for other traits important for commercialization along with chapati quality. This will help in not only assessing these genotypes for quality but will be useful for establishing a benchmark or a baseline as far as chapati quality is concerned.

The present study was thus largely built around the cultivars/genotypes which were known to excel for chapati quality. The major aim was to analyze the genotypes for their agronomic characteristics and to study their quality attributes in one environment.

\section{MATERIAL AND METHODS}

40 wheat genotypes were evaluated over a period of three years for their field performance and quality attributes (2007-09). The research project was largely built around the tall traditional cultivars of the predwarfing era, which were known to excel for chapati quality (Table 1). Varieties such as C 306 remain unsurpassed for chapati quality in the Indian wheat breeding programme to date. The set of cultivars and stocks used in the study included tall traditional wheats, namely C 306, C 273, C 518 and C 591 as the most important constituents. Further a set of present day cultivars excelling in yield and grain quality (PBW 509, PBW 550), yield and bread quality (DBW 16, PBW 533) and some good-grained advanced lines (PBW 531, PBW 534, PBW 554) were included to represent genotypes of highest overall worth obtained so far in terms of quality as well as yield. Besides these genotypes, stocks from the National Genetic Stocks Nursery (NGSN) which excelled in specific quality components were also included. Finally commercial cultivars that rule the farmer's fields by virtue of yield but are average for quality traits (PBW 343, PBW 502) were included to obtain a quality spectrum of sufficient amplitude.

The material was grown in replicated trials using standard agronomic practices with the aim of expressing the normal quality potential of the genotypes. The set genotypes sown during first year was re-constituted in second year with some changes. Unexpectedly, the genetic stocks DI 9 and DI 105 (the dwarf versions of C 306 and C 591 respectively) were found to yield less than or at par with their parental isolines. Also the chapati score was numerically less than both C 306 and C 591 , leading to their omission. Pusa 5-3, a high protein stock, had reddish grains and thus was left out in second year. The genotypes WH 423, WH 595, WH 800, KYZ K2K-13, PBW 509 and PBW 531 were replaced by Madhya Pradesh wheats such as HI 1418 and HI 1479 , known to have good chapati quality. The few cultivars that had emanated from crosses of superior chapati quality wheats with dwarf wheats formed another important component of this set and included WG 357, PBW 175, PBW 154 and PBW 226. These varieties were released in 1970s-80s and no longer command significant acreage, but are known to have good chapati quality. These genotypes along with others constituted the set for third year. Raj 1482, Raj 3077 and Raj 3765 along with UP 262 were also included in this set. These genotypes replaced the poor performing ones in the second year. A genotype adapted to Central India, Lok 1, was included for its superior chapati quality, probably derived from tall traditional variety NP 4 which is one of its parents. NP 4 has been known internationally for its superior quality.

Agronomic data recorded: The field performance of the genotypes was observed on the basis of following characteristics: Days to heading: recorded as number of days from date of sowing to $50 \%$ flowering. Plant height: measured in centi meter from base of plant to the tip of spike excluding the awns. Tiller number: recorded as numbers of tillers per meter. Number of 
Spikelets/Spike: Number of spikelets was counted on five randomly selected spikes and average was worked out. Spike yield: calculated as the weight of grains per spike. Spike grains: five spiked were threshed together and total grains were calculated for single spike, 1000 grain weight: as weight of thousand counted grains, Test weight: as weight per unit volume of wheat grains, Grain yield: Recorded as yield of plot in g/plot.

Chapati making characteristics: The whole meal was produced by grinding the grains in a laboratory stone grinder (Chakki). The gap between the two stone discs was adjusted so as to pass the meal through 40 micron mesh sieve. The $50 \mathrm{~g}$ whole meal (atta) and optimum quantity of water were mixed mechanically for $2 \mathrm{~min}$ using Swanson mixer. The dough was evaluated for stickiness while rounding it up manually and kept in the humidity cabinet maintained at $30^{\circ} \mathrm{C}$ and $80 \%$ R.H for $30 \mathrm{~min}$. The dough was sheeted to $2 \mathrm{~mm}$ thickness with the rolling pin and chapaties of $15.0 \mathrm{~cm}$ diameter were cut using appropriate die. Chapaties were baked on an automatic roti-maker having thermostatically controlled constant temperature for $20 \mathrm{sec}$ on one side and for $40 \mathrm{sec}$ on other. Finally it was puffed for 10 sec by turning the chapati and bringing the upper plate of the roti-maker in contact with the chapaties. Chapaties were cooled to room temperature in the humidity cabinet and evaluated by a panel of trained judges using the evaluation performa based on dough stickiness (5), puffing of chapati (5), color of chapati (5), texture of chapati (5), taste of chapati (5), flavor of chapati (5) and texture of chapati after $2 \mathrm{hrs}$ (5). The total score was finally calculated out of a maximum of 10 . The methodology has been derived from Rao et al. (1986) and Sekhon et al. (1991).

Statistical analysis: The material had been planted in a randomized complete block design. The analysis of variance for different traits was done as per the following model:

$\mathrm{Y}_{\mathrm{ij}}=\mathrm{m}+\mathrm{t}_{\mathrm{i}}+\mathrm{b}_{\mathrm{j}}+\mathrm{e}_{\mathrm{ij}}$

$Y_{i j}=$ observation obtained from the $i^{\text {th }}$ treatment and $j^{\text {th }}$ block.

$\mathrm{m}=$ general mean

$t_{i}=$ the effect of $i^{\text {th }}$ treatment

$b_{j}=$ the effect of $j^{\text {th }}$ block

$\mathrm{e}_{\mathrm{ij}}=$ error associated with $\mathrm{i}^{\text {th }}$ treatment and $\mathrm{j}^{\text {th }}$ block

The analysis of variance based on the above model takes the following form:

Where, $\mathrm{r}=$ no. of replications, $\mathrm{g}=$ no. of genotypes

\begin{tabular}{|c|c|c|c|c|}
\hline Source & d. f. & $\begin{array}{l}\text { Sum of } \\
\text { Squares }\end{array}$ & $\begin{array}{l}\text { Mean sum } \\
\text { of squares }\end{array}$ & F-ratio \\
\hline $\begin{array}{l}\text { Replica- } \\
\text { tions }\end{array}$ & $r-1$ & RSS & MSR & MSR/MSE \\
\hline $\begin{array}{l}\text { Treatments } \\
\text { Error }\end{array}$ & $\begin{array}{l}\mathrm{g}-1 \\
(\mathrm{r}-1)(\mathrm{g}-1)\end{array}$ & $\begin{array}{l}\text { GSS } \\
\text { SSE }\end{array}$ & $\begin{array}{l}\text { MST } \\
\text { MSE }\end{array}$ & MST/MSE \\
\hline
\end{tabular}

$\mathrm{CD}$ to compare two genotypes was computed as follows:

$$
\mathrm{CD}=\sqrt{\frac{2 \mathrm{MSE}}{\mathrm{r}}} \times \mathrm{t}_{\mathrm{a}}(\mathrm{r}-1)(\mathrm{g}-1)
$$

Where, $\mathrm{a}=$ level of significance

\section{RESULTS AND DISCUSSION}

Analysis of genetic variation for chapati quality was a major objective of the present study. It would be instructive to discuss the chapati quality of the set of genotypes collected from various wheat growing zones of India. This is the character the study seeks to explain in terms of various quality components and indices. Almost all the genotypes used in the study are known to have either one or the other attribute which contributes to superior end use quality.

Significant genotypic differences were observed for chapati score of the genotypes in all the three seasons. The mean chapati score (Table 1) ranged from 7.2 (Pusa 5-3) to 8.1 (C 306) during the first year. The chapati score showed variation between the groups of genotypes, with the tall wheats of pre dwarfing era excelling over other groups. The tall varieties not only established themselves as a distinct group with highest chapati score but the next numerical best score $(7.8$ for both DI 9 and DI 105) also went to the derivatives of C 306 and $\mathrm{C} 591$. The commercial high yielding cultivars gave intermediate chapati scores, significantly inferior to the best tall wheat i.e., C 306. Similar was the case of genetic stocks and other varieties which showed chapati scores well below the best entry i.e., C 306. Stocks excelling in one or more quality component. The advanced lines (PBW 531, PBW 534, PBW 554) used in the set performed almost similar to the commercially released varieties. On the whole the genetic stocks DI 9, DI 105 and WH 423 with chapati scores of 7.8, 7.8 and 7.7 respectively were adjudged to be at par with the best cultivar C 306 (Table 1).

During second year, significant genotypic differences were again observed for chapati score. The mean chapati score (Table 1) ranged from 7.1 in case of ' $\mathrm{PBW}$ 502 ' to 8.1 in case of ' $\mathrm{C} 306$ ' and ' $\mathrm{C} \mathrm{518}$ '. The tall varieties were again found significantly superior to all other groups, thus confirming their status as best chapati wheats. The commercial wheat group gave intermediate score with PBW 343 (7.6) having highest score in the group. DBW 16 and PBW 533 were included in the set as they are identified for their excellent bread making properties. These varieties did not fare well for chapati making giving a score of 7.4 only. This suggests that there is environmental influence on the chapati quality which is a quantitative trait. Among the released varieties known for chapati quality, Lok 1 (chapati score 7.9) performed better than others in the group though slightly lower than C 306. Thus Lok 1 was able to express good chapati quality outside Central Zone also, where it is recommended for cultivation. Similarly HI 1418 also registered a 
Satish Kumar et al. / J. Appl. \& Nat. Sci. 10 (1): 149 - 157 (2018)

Table 1. The set of genotypes evaluated for their chapati score during three years.

\begin{tabular}{|c|c|c|c|c|c|}
\hline \multicolumn{2}{|c|}{ Ist Year } & \multicolumn{2}{|c|}{ IInd Year } & \multicolumn{2}{|c|}{ IIIrd Year } \\
\hline Genotype & $\begin{array}{l}\text { Mean Chapati } \\
\text { score }\end{array}$ & Genotype & $\begin{array}{l}\text { Mean Chapati } \\
\text { score }\end{array}$ & Genotype & $\begin{array}{c}\text { Mean Chapati } \\
\text { score }\end{array}$ \\
\hline C 273 & 7.9 & $8 \mathrm{~A}$ & 7.9 & PBW 343 & 7.8 \\
\hline C 306 & 8.1 & 9D & 7.8 & PBW 550 & 7.8 \\
\hline C 518 & 8.0 & C 273 & 8.0 & PBW 533 & 7.5 \\
\hline C 591 & 8.0 & C 306 & 8.1 & PBW 534 & 7.6 \\
\hline WG 357 & 7.6 & C 518 & 8.1 & DBW 16 & 7.8 \\
\hline PBW 343 & 7.6 & C 591 & 8.0 & PBW 154 & 7.5 \\
\hline PBW 550 & 7.4 & WG 357 & 7.9 & PBW 175 & 7.5 \\
\hline PBW 502 & 7.4 & PBW 343 & 7.6 & PBW 226 & 7.5 \\
\hline PBW 509 & 7.6 & PBW 502 & 7.1 & LOK 1 & 8.0 \\
\hline PBW 554 & 7.6 & PBW 550 & 7.4 & $8 \mathrm{~A}$ & 8.0 \\
\hline PBW 531 & 7.6 & DBW 16 & 7.4 & 9D & 8.0 \\
\hline PBW 534 & 7.5 & PBW 533 & 7.4 & C 273 & 7.9 \\
\hline Pusa 5-3 & 7.2 & PBW 534 & 7.3 & C 306 & 8.3 \\
\hline DI 105 & 7.8 & PBW 554 & 7.6 & C 518 & 8.0 \\
\hline DI 9 & 7.8 & HI 1418 & 7.8 & C 591 & 8.0 \\
\hline WH 423 & 7.7 & HI 1479 & 7.5 & WG 357 & 7.7 \\
\hline WH 595 & 7.6 & PBW 154 & 7.2 & HD 2329 & 7.5 \\
\hline WH 712 & 7.5 & PBW 175 & 7.3 & HD 2733 & 7.7 \\
\hline KO 123 & 7.4 & PBW 226 & 7.3 & UP 262 & 7.9 \\
\hline KYZ K2K-13 & 7.5 & LOK 1 & 7.9 & WH 712 & 7.5 \\
\hline HD 2793 & 7.5 & KO 123 & 7.5 & WH 1003 & 7.5 \\
\hline WH 800 & 7.5 & HD 2793 & 7.6 & RAJ 1482 & 7.9 \\
\hline \multirow[t]{2}{*}{ WH 1003} & 7.4 & WH 712 & 7.3 & RAJ 3077 & 7.7 \\
\hline & & WH 1003 & 7.4 & RAJ 3765 & 7.8 \\
\hline Means & 7.5 & Means & 7.6 & Means & 7.7 \\
\hline CD $(5 \%)$ & 0.41 & CD (5\%) & 0.31 & CD $(5 \%)$ & 0.26 \\
\hline
\end{tabular}

chapati quality score of 7.8 , at par with C 306 . PBW 154 (7.2), PBW 175 (7.3) and PBW 226 (7.3) fell into next group with respect to chapati quality. These genotypes are regarded to be superior for chapati quality among released semi-dwarf varieties and PBW 175 has C-306 as a parent. The genetic stocks, on the other hand again failed to give good chapaties thus emphasizing the fact that good chapati quality resulted from a combination of different component traits and not because of one or two traits. The advanced breeding lines in this season again showed an intermediate chapati score.

During third year again significant genotypic differences were again observed for chapati score. The mean chapati score (Table 1) ranged from 7.4 in case of 'WH 712' to 8.3 in case of ' $\mathrm{C} 306$ '. As during first two years, tall traditional varieties were significantly superior in chapatti quality to all other groups. The commercial wheat group gave intermediate score with PBW 343 (7.8) having highest score in the group. Lok 1 (chapati score 8.0) again performed better along with Raj 1482 (7.9) and UP 262 (7.9).

The similar results were reported by earlier studies (Bakshi et al., 1979; Austin and Hanslas, 1983; Das et al., 2006; Hemalatha et al., 2006; Mehta et al., 2006) which emphasized that the tall traditional wheat varieties of pre-dwarfing era were superior in chapati quality in comparison to the semi dwarf varieties.

Evaluation of the genotypes for yield and other agronomic traits: Analysis of variance indicated that there are significant differences present among the genotypes across all the three years (Table 2a, 2b \& 2c). Mean performance of the genotypes across first, second and third year for different traits is given in the table 3 , table 4 and table 5 respectively. Trait wise discussion on evaluation of the genotypes is presented below:

Test weight: The test weight gives an account of the stresses suffered by the crop during the grain formation along with the indication of the shape and size of the grains. The values of test weight among the genotypes ranged from $75.00 \mathrm{~kg} / \mathrm{hl}$ for ' $\mathrm{WH} 423$ ' to $83.00 \mathrm{~kg} / \mathrm{hl}$ for 'C 591 and WH 800' during first year. All the genotypes in tall wheats group gave high values for test weight along with the commercial; wheats and the advanced lines known to have good grains. Only PBW 534 gave a value of $76.67 \mathrm{~kg} / \mathrm{hl}$. In case of genetic stocks medium to high values were obtained for all the genotypes except DI 9 (76 kg/hl), DI 105 (75.67) (chapati quality score not so low) and WH 423. In second year the values of test weight ranged from 73.50 $\mathrm{kg} / \mathrm{hl}$ for 'Lok 1' to $79.33 \mathrm{~kg} / \mathrm{hl}$ for 'C 591 '. Overall the values of test weight observed were on lower side in comparison to previous season. Again the values of test weight for tall wheats were highest in this season, whereas the commercial wheats, advanced lines and the varieties with known quality gave medium range of values. The genetic stocks however gave low values of 
Table 2a. Analysis of variance of evaluated during first year

\begin{tabular}{|c|c|c|c|c|c|c|c|c|c|c|}
\hline \multirow{2}{*}{$\begin{array}{l}\text { Source of } \\
\text { Variation }\end{array}$} & \multirow{2}{*}{$\begin{array}{l}\text { Degree of } \\
\text { freedom }\end{array}$} & \multicolumn{8}{|c|}{ Mean Squares } & \multirow[b]{2}{*}{$\begin{array}{c}\text { Yield (Kg/ } \\
\text { plot) }\end{array}$} \\
\hline & & $\begin{array}{c}\text { Days to } \\
\text { flowering } \\
(50 \%)\end{array}$ & $\begin{array}{c}\text { Plant } \\
\text { Height } \\
\text { (cm) }\end{array}$ & $\begin{array}{c}\text { Grains } \\
\text { per } \\
\text { spike }\end{array}$ & $\begin{array}{c}\text { Spike } \\
\text { yield } \\
(\mathrm{g})\end{array}$ & $\begin{array}{c}\text { No. of } \\
\text { spikelets } \\
\text { per spike }\end{array}$ & $\begin{array}{c}\text { Tillers } \\
\text { per } \\
\text { meter }\end{array}$ & $\begin{array}{c}1000 \\
\text { grains } \\
\text { weight }(\mathrm{g})\end{array}$ & $\begin{array}{c}\text { Test } \\
\text { weight } \\
\text { (g) }\end{array}$ & \\
\hline Replication & 2 & 0.97 & 48.12 & 3.89 & 0.017 & 3.02 & 218.26 & 14.16 & 4.59 & 20308.46 \\
\hline Genotypes & 22 & $36.90 *$ & 449.21 & $153.08 *$ & $0.36^{*}$ & 5.63 & $454.86^{*}$ & $55.70 *$ & $17.39 *$ & $40705.05 *$ \\
\hline Error & 44 & 2.21 & 11.84 & 54.05 & 0.10 & 1.47 & 137.35 & 4.54 & 3.85 & 14496.43 \\
\hline
\end{tabular}

* Significant at $5 \%$ level

Table 2b. Analysis of variance of evaluated during second year

\begin{tabular}{|c|c|c|c|c|c|c|c|c|c|c|}
\hline \multirow{2}{*}{$\begin{array}{l}\text { Source of } \\
\text { Variation }\end{array}$} & \multirow{2}{*}{$\begin{array}{l}\text { Degree of } \\
\text { freedom }\end{array}$} & \multicolumn{7}{|c|}{ Mean Squares } & \multirow[b]{2}{*}{$\begin{array}{c}\text { Test } \\
\text { weight } \\
\text { (g) }\end{array}$} & \multirow[b]{2}{*}{$\begin{array}{c}\text { Yield } \\
\text { (Kg/plot) }\end{array}$} \\
\hline & & $\begin{array}{c}\text { Days to } \\
\text { flowering } \\
(50 \%)\end{array}$ & $\begin{array}{l}\text { Plant } \\
\text { Heigh } \\
\text { t (cm) }\end{array}$ & $\begin{array}{c}\text { Grains } \\
\text { per } \\
\text { spike }\end{array}$ & $\begin{array}{c}\text { Spike } \\
\text { yield } \\
\text { (g) }\end{array}$ & $\begin{array}{c}\text { No. of } \\
\text { spikelets } \\
\text { per spike }\end{array}$ & $\begin{array}{c}\text { Tillers } \\
\text { per } \\
\text { meter }\end{array}$ & $\begin{array}{c}1000 \text { grains } \\
\text { weight (g) }\end{array}$ & & \\
\hline Replication & 2 & 1.33 & 339.85 & 88.62 & 0.14 & 4.43 & 3711.10 & 15.33 & 2.56 & 0.89 \\
\hline Genotypes & 23 & $218.34^{*}$ & 512.52 & $537.11 *$ & $1.39 *$ & 4.39 & 1041.71 & $45.54 *$ & $7.94 *$ & $1.08 *$ \\
\hline Error & 44 & 2.95 & 30.99 & 55.52 & 0.10 & 1.31 & 368.58 & 6.75 & 0.98 & 0.20 \\
\hline
\end{tabular}

* Significant at $5 \%$ level

Table 2c. Analysis of variance of evaluated during second year

\begin{tabular}{|c|c|c|c|c|c|c|c|c|c|c|}
\hline \multirow{2}{*}{$\begin{array}{l}\text { Source of } \\
\text { Variation }\end{array}$} & \multirow{2}{*}{$\begin{array}{l}\text { Degree of } \\
\text { freedom }\end{array}$} & \multicolumn{8}{|c|}{ Mean Squares } & \multirow[b]{2}{*}{$\begin{array}{c}\text { Yield } \\
\text { (Kg/ } \\
\text { plot) }\end{array}$} \\
\hline & & $\begin{array}{c}\text { Days to } \\
\text { flowering } \\
(50 \%)\end{array}$ & $\begin{array}{c}\text { Plant } \\
\text { Height } \\
\text { (cm) }\end{array}$ & $\begin{array}{c}\text { Grains } \\
\text { per } \\
\text { spike }\end{array}$ & $\begin{array}{c}\text { Spike } \\
\text { yield } \\
\text { (g) }\end{array}$ & $\begin{array}{c}\text { No. of } \\
\text { spikelets } \\
\text { per spike }\end{array}$ & $\begin{array}{c}\text { Tillers } \\
\text { per } \\
\text { meter }\end{array}$ & $\begin{array}{c}1000 \\
\text { grains } \\
\text { weight }(\mathrm{g})\end{array}$ & $\begin{array}{c}\text { Test } \\
\text { weight } \\
\text { (g) }\end{array}$ & \\
\hline Replication & 2 & 2.08 & 31.59 & 235.85 & 0.005 & 38.51 & 1049.97 & 17.25 & 15.84 & 0.02 \\
\hline Genotypes & 23 & $26.57 *$ & $511.86^{*}$ & 127.66 & $0.22 *$ & 6.58 & 459.76 & $41.18^{*}$ & 9.30 & $0.55^{*}$ \\
\hline Error & 44 & 9.73 & 28.35 & 73.56 & 0.10 & 2.45 & 295.02 & 11.10 & 4.48 & 0.15 \\
\hline
\end{tabular}

* Significant at $5 \%$ level

Table 3. Mean performance of genotypes for different agronomic traits and yield evaluated during first year.

\begin{tabular}{|c|c|c|c|c|c|c|c|c|c|}
\hline Genotype & $\begin{array}{l}\text { Days to } \\
\text { heading } \\
(50 \%)\end{array}$ & $\begin{array}{l}\text { Plant } \\
\text { height } \\
\text { (cm) }\end{array}$ & $\begin{array}{l}\text { No. of } \\
\text { grains / } \\
\text { spike }\end{array}$ & $\begin{array}{l}\text { Spike } \\
\text { yield } \\
\text { (g) }\end{array}$ & $\begin{array}{l}\text { No. of spike- } \\
\text { lets / spike }\end{array}$ & $\begin{array}{l}\text { Tillers/ } \\
\text { meter }\end{array}$ & $\begin{array}{l}\text { Yield } \\
\text { (Kg/ } \\
\text { plot) }\end{array}$ & $\begin{array}{l}1000 \\
\text { grains } \\
\text { wt.(g) }\end{array}$ & $\begin{array}{l}\text { Test } \\
\text { weight } \\
(\mathrm{kg} / \mathrm{hl})\end{array}$ \\
\hline C 273 & 93.0 & 102.0 & 39.0 & 1.3 & 18.0 & 91.0 & 2.26 & 31.0 & 81.0 \\
\hline C 306 & 94.0 & 101.0 & 47.0 & 1.7 & 19.0 & 70.0 & 3.27 & 35.0 & 79.0 \\
\hline C 518 & 95.0 & 105.0 & 48.0 & 1.7 & 18.0 & 114.0 & 4.83 & 33.0 & 81.0 \\
\hline C 591 & 96.0 & 114.0 & 58.0 & 1.9 & 19.0 & 102.0 & 3.63 & 30.0 & 83.0 \\
\hline WG 357 & 95.0 & 83.0 & 46.0 & 1.9 & 15.0 & 102.0 & 3.31 & 36.0 & 81.0 \\
\hline PBW 343 & 97.0 & 74.0 & 49.0 & 2.1 & 18.0 & 106.0 & 6.29 & 39.0 & 80.0 \\
\hline PBW 534 & 91.0 & 81.0 & 36.0 & 1.6 & 19.0 & 79.0 & 3.60 & 40.0 & 76.0 \\
\hline PBW 550 & 95.0 & 72.0 & 51.0 & 2.0 & 17.0 & 72.0 & 5.46 & 38.0 & 82.0 \\
\hline PBW 554 & 95.0 & 71.0 & 51.0 & 2.2 & 18.0 & 75.0 & 5.00 & 40.0 & 82.0 \\
\hline PBW 531 & 94.0 & 72.0 & 48.0 & 2.1 & 17.0 & 76.0 & 4.94 & 38.0 & 81.0 \\
\hline PBW 502 & 96.0 & 72.0 & 51.0 & 2.4 & 17.0 & 90.0 & 6.12 & 40.0 & 80.0 \\
\hline PBW 509 & 96.0 & 72.0 & 58.0 & 2.5 & 18.0 & 79.0 & 6.11 & 40.0 & 81.0 \\
\hline Pusa 5-3 & 94.0 & 88.0 & 42.0 & 1.7 & 18.0 & 102.0 & 4.54 & 32.0 & 78.0 \\
\hline DI 105 & 96.0 & 80.0 & 59.0 & 1.7 & 19.0 & 85.0 & 3.31 & 28.0 & 75.0 \\
\hline DI 9 & 99.0 & 83.0 & 53.0 & 1.7 & 17.0 & 77.0 & 2.83 & 27.0 & 76.0 \\
\hline WH 423 & 88.0 & 84.0 & 55.0 & 2.4 & 20.0 & 70.0 & 4.74 & 35.0 & 75.0 \\
\hline WH 595 & 96.0 & 78.0 & 60.0 & 2.2 & 19.0 & 92.0 & 5.08 & 35.0 & 77.0 \\
\hline WH 712 & 97.0 & 80.0 & 66.0 & 2.4 & 21.0 & 87.0 & 4.83 & 31.0 & 80.0 \\
\hline KO 123 & 96.0 & 68.0 & 52.0 & 1.8 & 19.0 & 97.0 & 6.34 & 31.0 & 80.0 \\
\hline KYZ & 87.0 & 83.0 & 50.0 & 2.4 & 17.0 & 85.0 & 4.61 & 42.0 & 80.0 \\
\hline HD 2793 & 101.0 & 82.0 & 50.0 & 1.6 & 18.0 & 82.0 & 5.64 & 35.0 & 79.0 \\
\hline WH 800 & 96.0 & 76.0 & 55.0 & 2.4 & 19.0 & 91.0 & 4.94 & 39.0 & 83.0 \\
\hline WH 1003 & 103.0 & 78.0 & 58.0 & 2.5 & 21.0 & 76.0 & 3.50 & 35.0 & 78.0 \\
\hline CD (5\%) & 2.4 & 5.6 & 2.6 & 0.5 & 1.9 & 14.6 & 0.98 & 3.5 & 3.2 \\
\hline
\end{tabular}

test weight with HD $2793(76.00 \mathrm{~kg} / \mathrm{hl})$ being an exception. During third year of evaluation the values of test weight among the genotypes ranged from 70.00 $\mathrm{kg} / \mathrm{hl}$ for 'PBW 343 and Raj 1482' to $77.00 \mathrm{~kg} / \mathrm{hl}$ for '8A, C 306 and PBW 534'. The performance during this year was similar to the performance of the genotypes during first two years.
Days to heading: During first year, he days to $50 \%$ heading ranged from 87.00 days for ' $\mathrm{KYZ}-\mathrm{K} 2 \mathrm{~K}-13$ ' to 103.00 days for 'WH1003'. The tall wheats, the commercial wheat varieties and the advanced lines gave equivalent values for the days to flowering whereas the genetic stocks showed a lot of variation for this trait. WH 423 (88.33 days) and KYZ K2K-13 gave 
Satish Kumar et al. / J. Appl. \& Nat. Sci. 10 (1): 149 - 157 (2018)

Table 4. Mean performance of genotypes for different agronomic traits and yield evaluated during second year

\begin{tabular}{lllllllllll}
\hline Genotype & $\begin{array}{l}\text { Days to } \\
\text { heading } \\
\mathbf{( 5 0 \% )}\end{array}$ & $\begin{array}{l}\text { Plant } \\
\text { height } \\
\text { (cm) }\end{array}$ & $\begin{array}{l}\text { No. } \\
\text { grains } \\
\text { spike }\end{array}$ & $\begin{array}{l}\text { of } \\
\text { / }\end{array}$ & $\begin{array}{l}\text { Spike } \\
\text { yield (g) }\end{array}$ & $\begin{array}{l}\text { No. } \\
\text { spikelets } / \\
\text { spike }\end{array}$ & $\begin{array}{l}\text { Tillers/ } \\
\text { meter }\end{array}$ & $\begin{array}{l}\text { Yield (Kg/ } \\
\text { plot) }\end{array}$ & $\begin{array}{l}\mathbf{1 0 0 0} \\
\text { grains wt. } \\
\text { (g) }\end{array}$ & $\begin{array}{l}\text { Test } \\
\text { weight } \\
\text { (Kg/hl) }\end{array}$ \\
\hline PBW 343 & 105.0 & 91.0 & 43.0 & 1.7 & 18.0 & 119.0 & 3.6 & 48.0 & 75.0 \\
PBW 502 & 105.0 & 94.0 & 34.0 & 1.5 & 18.0 & 106.0 & 3.5 & 48.0 & 75.0 \\
PBW 550 & 90.0 & 77.0 & 36.0 & 1.9 & 18.0 & 81.0 & 3.5 & 41.0 & 75.0 \\
DBW 16 & 106.0 & 89.0 & 35.0 & 1.5 & 16.0 & 111.0 & 3.3 & 41.0 & 77.0 \\
PBW 154 & 89.0 & 89.0 & 25.0 & 1.2 & 18.0 & 107.0 & 2.5 & 44.0 & 75.0 \\
PBW 175 & 103.0 & 102.0 & 33.0 & 1.6 & 16.0 & 160.0 & 2.2 & 45.0 & 75.0 \\
PBW 226 & 82.0 & 83.0 & 33.0 & 1.4 & 17.0 & 120.0 & 3.2 & 39.0 & 76.0 \\
PBW 533 & 101.0 & 94.0 & 22.0 & 1.5 & 17.0 & 116.0 & 3.8 & 52.0 & 76.0 \\
PBW 534 & 91.0 & 81.0 & 36.0 & 1.6 & 19.0 & 79.0 & 3.6 & 40.0 & 76.0 \\
PBW 554 & 89.0 & 78.0 & 38.0 & 2.0 & 19.0 & 74.0 & 3.4 & 42.0 & 76.0 \\
8A & 102.0 & 108.0 & 35.0 & 1.7 & 17.0 & 125.0 & 1.9 & 44.0 & 79.0 \\
9D & 100.0 & 121.0 & 32.0 & 1.5 & 19.0 & 118.0 & 1.7 & 41.0 & 78.0 \\
C 273 & 97.0 & 115.0 & 31.0 & 1.2 & 18.0 & 104.0 & 1.4 & 37.0 & 76.0 \\
C 306 & 96.0 & 114.0 & 29.0 & 1.4 & 18.0 & 112.0 & 2.3 & 44.0 & 78.0 \\
C 518 & 100.0 & 113.0 & 28.0 & 1.3 & 18.0 & 114.0 & 1.6 & 41.0 & 78.0 \\
C 591 & 98.0 & 122.0 & 21.0 & 1.5 & 19.0 & 128.0 & 1.8 & 39.0 & 79.0 \\
WG 357 & 99.0 & 95.0 & 27.0 & 1.4 & 18.0 & 112.0 & 2.9 & 44.0 & 76.0 \\
LOK 1 & 88.0 & 93.0 & 23.0 & 1.0 & 16.0 & 117.0 & 1.3 & 44.0 & 73.0 \\
HI 1418 & 86.0 & 85.0 & 32.0 & 1.3 & 18.0 & 111.0 & 2.8 & 36.0 & 74.0 \\
HI 1479 & 87.0 & 92.0 & 35.0 & 1.6 & 19.0 & 107.0 & 2.6 & 42.0 & 74.0 \\
KO 123 & 103.0 & 84.0 & 39.0 & 1.6 & 19.0 & 122.0 & 3.5 & 37.0 & 76.0 \\
HD 2793 & 115.0 & 99.0 & 42.0 & 1.6 & 20.0 & 94.0 & 3.0 & 37.0 & 76.0 \\
WH 712 & 103.0 & 96.0 & 35.0 & 1.6 & 20.0 & 126.0 & 3.0 & 37.0 & 74.0 \\
WH 1003 & 114.0 & 95.0 & 37.0 & 1.6 & 20.0 & 83.0 & 2.7 & 41.0 & 73.0 \\
CD (5\%) & $\mathbf{2 . 8}$ & $\mathbf{9 . 1}$ & $\mathbf{2 . 3}$ & $\mathbf{0 . 2}$ & $\mathbf{1 . 8}$ & $\mathbf{2 1 . 0}$ & $\mathbf{0 . 7}$ & $\mathbf{4 . 2}$ & $\mathbf{1 . 6}$ \\
\hline
\end{tabular}

low values whereas HD 2793 (101.33 days) and WH 1003 gave high values. Other genetic stocks were observed to have values intermediate to these extremes. In year the days to $50 \%$ heading ranged from 82.00 days for 'PBW 226' to 114.00 days for 'WH 1003'. Higher values for the days to heading were observed in this season. The tall wheats were found to have high values with $\mathrm{C} 518$ (100.33 days), 8A (102.00 days) and 9D (100.67 days) giving higher values than other varieties in this group. The commercial varieties, advanced lines and the genetic stocks were observed to show a lot of variation with both highest and lowest values giving a lot of difference. During third year the days to $50 \%$ heading ranged from 91.00 days for 'PBW 226' to 105.00 days for 'PBW 175'. Values of days to heading were even higher during this year. A mixed pattern was observed among different groups.

Plant height: Variation for plant height in genotypes ranged from $71.22 \mathrm{~cm}$ for 'PBW 554' to $114.66 \mathrm{~cm}$ for ' $\mathrm{C} 591$ ' in first year. The tall wheat varieties expressed their character with all the tall group wheats showing high values of plant height. The commercial group however gave lowest plant height values as most of the varieties had dwarfing genes. The genetic stocks and the advanced lines gave intermediate values of plant height in this season. In second year the values of plant height varied from $77.92 \mathrm{~cm}$ for 'PBW 550' to 122.17 $\mathrm{cm}$ for ' $\mathrm{C} 591$ '. As during first year different groups of genotypes followed similar trends. During third year the values of plant height varied from $73.00 \mathrm{~cm}$ for
'HD 2329 and LOK 1' to $125.00 \mathrm{~cm}$ for 'C 273'. Similar trends in plant height for the genotypes were again observed in this season. The tall wheats were observed to have highest value of plant height followed by varieties with known quality and the genetic stocks, which again showed values ranging from low to medium for plant height. The commercial wheat varieties gave low to intermediate values of plant height in this season.

Number of grains per spike: The number of grains per spike ranged from 36.20 for 'PBW 534' to 66.53 for ' $\mathrm{K} 0123$ ' in first year. The tall wheats and the advanced lines were found to have intermediate values for grains per spike. The genetic stocks and the commercial wheats however gave more number of grains per spike. In second year the number ranged from 21.93 for ' $\mathrm{C} 591$ ' to 42.60 for 'HD 2793'. The number of grains per spike in this season was lower in comparison to first year. Cultivars such as PBW 154 (25.93) and PBW 533 (22.27) gave low values whereas the commercial varieties as well as the genetic stocks gave high values of number of grains per spike. The tall wheats gave intermediate number of grains per spike. During third year, the number ranged from 29.00 for 'PBW 175 and WG 357' to 51.00 for '9D'. No particular trend was observed for this trait among the genotypes during third year of testing.

Spike yield: The spike yield showed variation from $1.35 \mathrm{~g}$ for ' $\mathrm{C} 273$ ' to $2.52 \mathrm{~g}$ for ' $\mathrm{WH} 1003$ ' in first year. The tall wheats gave low spike yield whereas the commercial varieties and the advanced lines gave high 
Satish Kumar et al. / J. Appl. \& Nat. Sci. 10 (1): 149 - 157 (2018)

Table 5. Mean performance of genotypes for different agronomic traits and yield evaluated during third year

\begin{tabular}{|c|c|c|c|c|c|c|c|c|c|}
\hline Genotype & $\begin{array}{l}\text { Days to } \\
\text { heading } \\
(50 \%)\end{array}$ & $\begin{array}{l}\text { Plant } \\
\text { height } \\
\text { (cm) }\end{array}$ & $\begin{array}{l}\text { No. of } \\
\text { grains } \\
\text { spike }\end{array}$ & $\begin{array}{l}\text { Spike } \\
\text { yield (g) }\end{array}$ & $\begin{array}{l}\text { No. of } \\
\text { spikelets / } \\
\text { spike }\end{array}$ & $\begin{array}{l}\text { Tillers/ } \\
\text { meter }\end{array}$ & $\begin{array}{l}\text { Yield (Kg/ } \\
\text { plot) }\end{array}$ & $\begin{array}{l}\text { 1000 } \\
\text { grains } \\
\text { wt. (g) }\end{array}$ & $\begin{array}{l}\text { Test } \\
\text { weight } \\
\text { (Kg/hl) }\end{array}$ \\
\hline $8 \mathrm{~A}$ & 99.0 & 109.0 & 37.0 & 1.3 & 19.0 & 59.0 & 1.1 & 33.0 & 77.0 \\
\hline 9D & 101.0 & 112.0 & 51.0 & 1.7 & 20.0 & 80.0 & 0.9 & 33.0 & 74.0 \\
\hline C 273 & 96.0 & 125.0 & 40.0 & 1.2 & 18.0 & 97.0 & 1.1 & 30.0 & 76.0 \\
\hline C 306 & 103.0 & 123.0 & 36.0 & 1.3 & 18.0 & 80.0 & 1.6 & 36.0 & 77.0 \\
\hline C 518 & 104.0 & 117.0 & 37.0 & 1.2 & 20.0 & 100.0 & 1.2 & 32.0 & 74.0 \\
\hline C 591 & 99.0 & 115.0 & 38.0 & 1.3 & 20.0 & 102.0 & 1.1 & 34.0 & 76.0 \\
\hline DBW 16 & 94.0 & 90.0 & 43.0 & 1.5 & 17.0 & 97.0 & 2.2 & 35.0 & 75.0 \\
\hline HD 2329 & 97.0 & 73.0 & 30.0 & 0.7 & 17.0 & 52.0 & 0.8 & 25.0 & 72.0 \\
\hline HD 2733 & 95.0 & 84.0 & 46.0 & 1.3 & 19.0 & 52.0 & 1.7 & 28.0 & 75.0 \\
\hline LOK 1 & 95.0 & 73.0 & 33.0 & 0.5 & 15.0 & 63.0 & 0.4 & 33.0 & 72.0 \\
\hline PBW 154 & 96.0 & 83.0 & 36.0 & 1.3 & 18.0 & 81.0 & 1.3 & 36.0 & 74.0 \\
\hline PBW 175 & 105.0 & 97.0 & 29.0 & 1.1 & 16.0 & 89.0 & 1.5 & 39.0 & 71.0 \\
\hline PBW 226 & 91.0 & 79.0 & 30.0 & 1.0 & 14.0 & 88.0 & 1.6 & 34.0 & 76.0 \\
\hline PBW 343 & 101.0 & 95.0 & 35.0 & 1.2 & 20.0 & 94.0 & 2.3 & 34.0 & 70.0 \\
\hline PBW 533 & 102.0 & 95.0 & 46.0 & 1.8 & 21.0 & 75.0 & 2.1 & 39.0 & 72.0 \\
\hline PBW 534 & 101.0 & 79.0 & 43.0 & 1.6 & 18.0 & 69.0 & 2.0 & 37.0 & 77.0 \\
\hline PBW 550 & 100.0 & 81.0 & 36.0 & 1.2 & 21.0 & 67.0 & 2.3 & 35.0 & 74.0 \\
\hline RAJ 1482 & 104.0 & 78.0 & 35.0 & 0.8 & 17.0 & 56.0 & 1.1 & 23.0 & 70.0 \\
\hline RAJ 3077 & 101.0 & 81.0 & 30.0 & 0.8 & 18.0 & 81.0 & 1.1 & 25.0 & 71.0 \\
\hline RAJ 3765 & 100.0 & 79.0 & 40.0 & 1.1 & 20.0 & 74.0 & 1.6 & 29.0 & 72.0 \\
\hline UP 262 & 104.0 & 85.0 & 39.0 & 1.2 & 19.0 & 74.0 & 1.3 & 29.0 & 74.0 \\
\hline WG 357 & 97.0 & 93.0 & 29.0 & 0.9 & 18.0 & 73.0 & 1.1 & 31.0 & 73.0 \\
\hline WH 1003 & 100.0 & 90.0 & 49.0 & 1.7 & 20.0 & 76.0 & 2.3 & 34.0 & 72.0 \\
\hline WH 712 & 100.0 & 87.0 & 33.0 & 0.9 & 21.0 & 59.0 & 1.3 & 26.0 & 72.0 \\
\hline CD (5\%) & 6.4 & 11.2 & 3.4 & 0.6 & 3.2 & 6.7 & 0.8 & 5.4 & 4.3 \\
\hline
\end{tabular}

Table 6. Mean performance of genotypes during core group for three years

\begin{tabular}{lllllllllll}
\hline Genotype & $\begin{array}{l}\text { Days to } \\
\text { heading } \\
\text { (50\%) }\end{array}$ & $\begin{array}{l}\text { Plant } \\
\text { height } \\
\text { (cm) }\end{array}$ & $\begin{array}{l}\text { No. of } \\
\text { grains } \\
\text { /spike }\end{array}$ & $\begin{array}{l}\text { Spike } \\
\text { yield } \\
\text { (g) }\end{array}$ & $\begin{array}{l}\text { No. } \\
\text { spikelets } \\
\text { spike }\end{array}$ & $\begin{array}{l}\text { Tillers/ } \\
\text { meter }\end{array}$ & $\begin{array}{l}\text { Yield } \\
\text { (Kg/plot) }\end{array}$ & $\begin{array}{l}\text { 1000 } \\
\text { grains } \\
\text { wt. }(\mathbf{g})\end{array}$ & $\begin{array}{l}\text { Test } \\
\text { weight } \\
\text { (Kg/hl) }\end{array}$ & $\begin{array}{l}\text { Chapati } \\
\text { score (out } \\
\text { of } \mathbf{~ 1 0 )}\end{array}$ \\
\hline C 273 & 95.7 & 114.7 & 36.7 & 1.2 & 18.4 & 97.4 & 1.3 & 33.3 & 78.4 & 7.93 \\
C 306 & 97.9 & 113.1 & 37.7 & 1.5 & 18.8 & 87.8 & 2.0 & 38.9 & 78.2 & 8.17 \\
C 518 & 100.1 & 112.2 & 38.2 & 1.4 & 19.1 & 109.8 & 1.4 & 35.8 & 78.3 & 8.03 \\
C 591 & 97.9 & 117.5 & 39.9 & 1.6 & 19.7 & 111.2 & 1.5 & 34.8 & 79.7 & 8.00 \\
HD 2733 & 103.9 & 88.8 & 46.7 & 1.6 & 19.5 & 76.3 & 2.4 & 33.7 & 76.7 & 7.60 \\
PBW 343 & 101.2 & 87.2 & 39.6 & 1.7 & 19.5 & 106.9 & 3.0 & 41.0 & 75.4 & 7.67 \\
PBW 534 & 94.5 & 80.7 & 38.8 & 1.6 & 19.2 & 76.1 & 2.8 & 39.8 & 77.0 & 7.47 \\
PBW 550 & 95.3 & 77.2 & 41.5 & 1.7 & 19.1 & 73.9 & 2.9 & 38.6 & 77.5 & 7.53 \\
WG 357 & 97.2 & 91.0 & 34.2 & 1.4 & 17.6 & 96.1 & 2.0 & 37.1 & 77.3 & 7.73 \\
WH 1003 & 105.7 & 88.1 & 48.7 & 1.9 & 20.9 & 78.8 & 2.5 & 37.2 & 74.7 & 7.43 \\
WH 712 & 100.6 & 88.0 & 45.2 & 1.7 & 21.2 & 91.2 & 2.2 & 31.9 & 75.9 & 7.40 \\
\hline
\end{tabular}

values with PBW 534 (1.64) being only exception in the group. The genetic stocks gave values for spike yield ranging from medium to high. In second year the variation ranged from $1.01 \mathrm{~g}$ for 'Lok 1' to $2.04 \mathrm{~g}$ for 'PBW 554'. Again in this season the values of spike yield were observed to be on lower side in comparison to first year. During third year the variation ranged from $0.5 \mathrm{~g}$ for 'Lok 1' to $1.8 \mathrm{~g}$ for 'PBW 534'. Again in this season the values of spike yield were observed to be on lower side in comparison to first two years. The tall wheats gave low spike yield whereas the commercial varieties and the advanced lines gave intermediate to high values. The genetic stocks were found to have medium to high spike yields.

Number of spikelets per spike: The number of spikelets per spike ranged from 15.88 for ' $W G 357$ ' to 21.89 for 'WH 1003' in first year, where as in second year the number varied from 16.03 for ' $\mathrm{PBW} 175$ ' to
20.77 for 'WH 1003'. During third year the range varied from 14.00 for 'PBW 226' to 21.00 for 'PBW 533 and PBW 550'. The number of spikelets per spike was not observed to be significantly different in all the genotypes studied.

Tillers per meter: The number of tillers per meter was highest in C 518 (114.00) and lowest in C 306 (70.37) during first year. The tall wheats with an exception of C 306 gave high values of tillers per meter whereas in commercial varieties group all genotypes gave medium values of tillers per meter with PBW 343 (106.67) being an exception. The advanced lines and the genetic stocks gave medium low values of tillers per meter. In the second year of evaluation WH 712 (126.83) and PBW 554 (74.67) showed highest and lowest number of tillers per meter respectively. During the third year the number of tillers per meter was highest in C 591 (102.00) and lowest in HD 2329 and HD 
2733 (52.00) The tall wheats and the varieties with known quality were observed to give high values for this trait. The advanced lines gave low values whereas the genetic stocks gave values ranging from medium to high.

1000 grains weight: The 1000 grain weight varied from $27.18 \mathrm{~g}$ for 'DI 9' to $42.54 \mathrm{~g}$ for 'KYZ-K2K-13' in first year. The advanced lines with good grains and the commercial varieties gave high 1000 grain weight values in comparison to tall wheats which gave medium range of values for this trait. All the genetic stocks with an exception of KYZ-K2K-13 (42.54 g) and WH 800 (39.31 g) gave low to medium range of values. The range was from $36.75 \mathrm{~g}$ for ' $\mathrm{HI} 1418$ ' to $52.07 \mathrm{~g}$ for 'PBW 533' in second year. In comparison to previous season the values of 1000 grain weight were on higher side in this season. Higher values were obtained for commercial wheats such as PBW 343 (48.56 g) and PBW 502 (48.96 g). Most of other genotypes gave medium range of values with few genetic stocks recording low values for the trait. During third year of evaluation the 1000 grains weight ranged from 23.00 in Raj 1482 to 39.00 in PBW 175 and PBW 533.

Plot yield: The yield showed range from $2600.00 \mathrm{~g}$ for 'C 273' to $6340.00 \mathrm{~g}$ for ' $\mathrm{K} 0123$ ' in first year. The tall wheats gave low values with C 518 (4830.67 g) being an exception. The commercial wheats gave high values with advanced lines and the genetic stocks yielding intermediate values for the plot yield. In second year the range for plot yield was from observed to be between $1310 \mathrm{~g}$ for 'Lok 1' and $3830 \mathrm{~g}$ for (PBW 533). The commercial varieties gave high values whereas tall wheats were observed to have low plot yields with C 306 (2300 g) being an exception. During third year of evaluation the plot yield for the genotypes ranged from $400.00 \mathrm{~g}$ in Lok 1 to $2300.00 \mathrm{~g}$ in PBW 550. The varieties with known quality also gave medium low values whereas advanced lines and the genetic stocks gave medium high values of plot yield across the years.

Results from a core set of genotypes evaluated during all three years: Over this period of testing, 11 genotypes were evaluated across all the three years. These genotypes formed the core group of genotypes which included the tall wheats of pre dwarfing era known for best chapati quality and few high yielding varieties released for cultivation along with two genetic stocks which performed better during each year. The mean chapati score of these genotypes revealed that the tall varieties had a distinct edge over others and are the best resource available for this trait. C 306 had a high mean chapati score of 8.17 followed by C 518, C 591 and C 273 (Table 6). The released varieties WG 357, HD 2733 and PBW 343 were intermediate in chapati quality whereas the genetic stocks WH 1103 and WH 712 had lowest score in the group. Among other agronomic traits recorded the traditional varieties were tall and had lower yields than the recently released varieties. The tall varieties had a slightly higher test weight. The quality attributes of these genotypes have been established by past studies (Uprety and Abrol, 1972; Qarooni, 1996; Singh, 2002; Singh and Gupta, 2004; Srivastava et al., 2003; Mallick et al., 2013; Hemalatha et al., 2013, Kundu et al., 2016).

This study for evaluating the performance of Indian wheat varieties known for good chapati making quality revealed that the tall traditional wheats from predwarfing era are still unmatched for their unique end use quality for the Indian flat breads commonly known as chapattis. Similar studies of quality parameters of Indian wheat varieties (Sekhon et al., 1976; Singh et al., 1983; Syed et al., 1990; Supekar et al., 2005; Gill et al., 2006, Inamdar et al., 2015; Harshwardhan et al., 2016) have indicated that there is a wide variation for various physico-chemical characteristics but majority of the varieties produce average to good chapaties. Chapati quality evaluation of candidate varieties and checks conducted under the All India Coordinated programme over three decades have shown variety C 306 to be superior to almost all the other cultivars tested (Mishra, 1998). Bansal et al. (2000) studied the suitability of advanced wheat genotypes for bread, biscuit and chapaties and reported some new genotypes to be better than the check varieties but none could surpass the best chapati wheat, C 306. Gupta et al. (2005) while working on wheat samples collected from different zones of India found that the location has some influence on chapati quality. It was found that some genotypes performed better in specific environments.

\section{Conclusion}

The performance of the varieties released after semi dwarf wheat were introduced in India and various genetic stocks developed for different component traits was found below par across all the three years of evaluation. The varieties from warm and humid central areas of India, did not perform to their potential when grown in northwestern plains which experience high temperatures during grain filling. The environmental conditions and the quantitative nature of the chapati quality did not auger well with the set of genotypes tested however, better and stable performance of the tall traditional varieties. C 306 the wheat variety released in 1965 for cultivation has remained the best quality genotype over the years and was also established from this study. The present study provides an established base for further studies on understanding the basis of chapati making quality of wheat. To infer the role of component traits in chapati quality some specific recombinant populations can be used. The knowledge generated during this study can be utilized for developing wheat genotypes with excellent end use quality. 


\section{REFERENCES}

Anonymous (2017). Director's Report of AICRP on Wheat and Barley 2016-17, Eds: Gyanendra Pratap Singh. ICAR-Indian Institute of Wheat and Barley Research, Karnal, Haryana, India. P. 92.

Abrol, Y.P. (1972). Studies on chapati quality: Discoloration of chapaties. Bull. Grain Technol., 10: 41-46.

Austin, A. and Ram, A. (1971). Studies on chapati making quality of wheat. Rajendra Printers, Ram Nagar, New Delhi, $p p$ 1-108.

Austin, A. and Hanslas, V.K. (1983). Quality characteristics of Indian wheat cultivars. Wheat Project Directorate, IARI, New Delhi.

Bansal, G., Singh, R.P. and Nanda, G.S. (2000). Suitability of advanced wheat genotypes for bread, biscuit and chapaties. J. Res. Punjab Agric. Univ., 47: 63-70.

Bakshi, A.K., Sekhon, K.S., Sehgal, K.L. and Gill, K.S. (1979). Chapati making performance of some promising wheat strains. J. Res. Punjab Agric. Univ., 26:267-271

Das, B.K., Sharma, A., Marathe, S.A., Rao, V.S. and Bhagwat, S.G. (2006). Evaluation of bread and chapati making quality of wheat selections and parents differing in HMW subunits of glutenin. J. Food Sci. Technol., 43: 69-72.

Finney, P.L., Bains, G.S., Hoseney, R.C. and Lineback, D.R. (1973). Quality of Indian wheats. Cereal Sci. Today, 18 (12): 392-397.

Gill, B.S., Singh, N. and Sodhi, N.S. (2006). Studies on physico-chemical, textural and functional properties of wheat flour from different Indian cultivars. J. Food Sci. Technol., 43: 56-64.

Gupta, R.K., Mohan, D., Ram, S. and Shoran, Jag. (eds) DWR Progress Report, (2005). Wheat Quality, AICW and BIP, Vol.4, Directorate of Wheat Research, Karnal132001.

Harshwardhan, Kumar, A., Kumar, A. and Prasad, B. (2016). Study of variance, heritability and genetic advance for various yield contributing and quality traits in spring wheat (Triticum aestivum L.). Journal of Applied and Natural Science, 8(4): 1811-1814.

Hemalatha, M.S., Manu, B.T., Bhagwat, S.G., Leelavathi, K. and Rao, U.J.S.P. (2006). Protein characteristics and peroxidase activities of different Indian wheat varieties and their relationship to chapati-making quality. European Food Res. Technol., 225: 463-471.

Hemalatha, M., Manohar, R.S., Salimath, P.S. and Rao, U.J.S.P. (2013). Effect of Added Arabinoxylans Isolated from Good and Poor Chapati Making Wheat Varieties on Rheological Properties of Dough and Chapati Making Quality. Food and Nutrition Sciences, 4:884-892

Inamdar, A.A., Sakhare, S.D. and Prabhasankar, P. (2015). Chapati Making Quality of Whole Wheat Flour (Atta) Obtained by Various Processing Techniques. Journal of Food Processing and Preservation, 39: (6) 3032-3039.

International Grains Council (2017) http://agricoop.nic.in/ sites/default/files/Wheat.pdf

Kumar, S. (2009). Association of physico-chemical, rheological and molecular indices of quality with chapati mak- ing properties in recombinant wheat populations. $P h D$ thesis. Punjab Agricultural University, Ludhiana.

Kundu, M., Gulia, N. and Khatkar, B.S. (2016). Diversity in Quality Traits of Indian Wheat Cultivars: Grain, Whole Wheat Flour and Protein Characteristics. International Journal of Innovative Research in Science, Engineering and Technology, 5(10): 17590-17594.

Mallick, S.A., Azaz, K., Gupta, M., Sharma, V. and Sinha, B.K. (2013). Characterization of grain nutritional quality in wheat. Ind J Plant Physiol., 18(2): 183-186.

Mehta, A., Mandeep, K., Gupta, S.K. and Singh, R.P. (2006). Physicochemical, rheological and baking characteristics of bread wheat as affected by farmyard manure and nitrogen management. J. Res. Punjab Agric. Univ., 43: 263-270.

Mishra, B.K. (1998). Quality needs for Indian traditional products. In: Wheat: Research Needs Beyond 2000 A D. Narosa Publishing House, New Delhi.

Panghal, A., Chhikara, N. and Khatkar, B.S. (2017). Characterization of Indian wheat varieties for chapati (flat bread) quality. Journal of the Saudi Society of Agricultural Sciences, http://dx.doi.org/10.1016/j.jssas. 2017.02.005.

Qarooni, J. (1996). Wheat characteristics for flat breads. Cereal Foods World, 41: 391-395.

Rao, H.P., Leelvathi, K. and Shurpalekar, S.R. (1986). Test baking of chapati development of a method. Cereal Chem., 63: 297-303.

Sekhon, K.S., Sharma, S. and Nagi, H.P.S. (1991). Technology of flat bread production. Indian Baker, 22: 18-19.

Sekhon, K.S., Bakshi, A.K., Sehgal, K.L. and Gill, K.S. (1976). Studies on the physico chemical and rheological characteristics of some improved wheat verities. Indian J. Biochem. Biopys., 13: 22.

Singh, R.P. (2002). Wheat flour: use of supplements for making better quality chapaties. Indian Grains, 49:18-20

Singh, R.P. and Gupta, S.K. (2004). Quality characteristics of the newly released wheat varieties. India Miller, 35: 25-29.

Singh, S., Verma, A. and Bala, N. (2016). Sensory and nutritional evaluation of unleavened flat bread prepared by multigrain flour mixture. Journal of Applied and Natural Science, 8(3): 1168-1171.

Singh, R.P., Sehgal, K.L., Saxena, A.K., Sekhon, K.S. and Gill, K.S. (1983). Physico chemical, rheological and baking characteristics of some promising strains of wheat. J. Res. Punjab Agric. Univ., 20: 403-410.

Srivastava, A.K., Rao, J.S.P. and Rao, P.H. (2003). Studies on protein and its high molecular weight subunit composition in relation to chapati making quality of Indian wheat cultivars. J. Sci. Food Agric., 83: 225-231.

Supekar, D.T., Patil, S.R. and Munjal, S.V. (2005). Comaprative study of some important aestivum, durum and dicoccum wheat cultivars for grain, flour quality and suitability for chapati making characteristics. $J$. Food Sci. Technol., 42: 488-492.

Syed, H.M. (1990). Indian wheats in relation to Chapati: a review. Indian Miller, 21: 17-20.

Uprety, D.C. and Abrol, Y.P. (1972). Studies on Chapati quality. Bull. Grain Tech., 10: 276-282. 